\title{
Application of Law Information and Electronic Transactions in Crime Investigation of Online Gambling
}

\author{
Farris Nur Sanjaya ${ }^{1}$ \\ Abstract. Internet in Indonesia has an important influence on the shape of society. \\ All of lifestyle conveniences provided, of course, continue to provide a negative \\ influence on the life of the nation. Crime using the internet is also increasing, one of \\ the crime of online gambling. So that the police in order to conduct an investigation \\ into the crime of online gambling, using the Law of the Republic of Indonesia \\ Number 11 of 2008 on Information and Electronic Transactions (Act of ITE). With \\ the provision regulating digital evidence and electronical proof in Act of ITE, it would \\ be easier for the police in evidence and law enforcement against the perpetrators of \\ the crime of online gambling. \\ Keywords: Act of ITE, Investigations, Online gambling.
}

\section{Introduction}

In the development of advanced computer technology presence to the Internet network has brought great benefits to humans. Utilization not only in government, private sector / enterprise, but has reached in all sectors of life including all household purposes (private). ${ }^{2}$ However, advances in information technology (internet) and any benefits in it brings negative consequences of its own where the more easily the criminals to commit crimes are increasingly concerned about the community. A theory suggests that crime is the product of society it self, which simply means that the higher the intellectual level of a society it will be increasingly sophisticated and diverse, also the level of crime that can happen. $^{3}$

In Indonesia, gambling is a form of crime that can be subject to criminal sanctions. ${ }^{4}$ In essence, gambling is contrary to Religion, Decency and Morals Pancasila, as well as endangering the livelihoods and lives of the people, nation, and state. ${ }^{5}$

In the Indonesian positive law the crime of gambling in the network to distinguish from ordinary criminal offenses a gambler. The criminal act of gambling in specially arranged network in article 27 paragraph 2 of the Law of the Republic of Indonesia Number 11 of 2008 on Information and Electronic Transactions (Act of ITE) while the regular gambling in general governed by the rules contained in Article 303 of the Criminal Code.

The principle is the foundation or something that made the footstool of thought, speech and action. The principles forming the legislation means that basic or something that made a footstool in drafting the legislation. In the provision of Article 63 paragraph 2 of the Code of Criminal Law (hereinafter referred to as the Criminal Code) contained Principle Lex Specialist derogate Lex Generalis which is a principle of interpretation of the law which

\footnotetext{
${ }^{1}$ Police Students Master Program (S2) of Law UNISSULA email: farrissnursanjaya@gmail.com

${ }^{2}$ Widyopramono Hadi Widjojo Cyber Crimes dan Pencegahannya Jurnal Hukum Teknologi Fakultas Hukum Universitas Indonesia Vol 22005 p. 7.

${ }^{3}$ Abdul Wahib dan Mohammad Labib Kejahatan Mayantara (Cybercrime) Kejahatan Mayantara (Cybercrime) Bandung: Refika Aditama 2005 p. 39

${ }^{4}$ Law No. 7 of 1974 on Control Gambling Article 1.

${ }^{5}$ Muhammad Fajrul Falah dkk Perjudian Online: Kajian Pidana atas Putusan Nomor 1033/PID.B/2014/PN.BDG e-Journal Lentera Hukum 2 Vol. 1 University of Jember 2017 p. 29.
} 
states that the law of a specific nature (lex) override the general law (lex generalis). ${ }^{6}$ In the Criminal Code already set about tintak criminal gambling but these rules are general (lex generalis) while at the Law of the Republic of Indonesia Number 11 Of 2008 on Information and Electronic Transactions (Act of ITE) also regulates the crime of gambling that have specific elements such as element clause contained in article 27 paragraph 2 of the elements: distributing, transmitting, and elements made inaccessibility. So it can be said that the Law of the Republic of Indonesia Number 11 Of 2008 on Information and Electronic Transactions (Act of ITE) is a rule that is special (Lex Specialist) of the Criminal Code.

Gambling in the network (internet gambling, online gambling or cyberspace gambling) is gambling which is done by using electronic technology that can be used to access electronic documents and electronic information. In the virtual world, gambling including the largest commercial community. In general, the methods used tend to be classic gambling, namely by staking or just try their luck with the following instructions gambling predetermined models. There are tens of thousands more sites on the internet that provide gambling facilities of the classical model, which only played the keyboard function keys to highly sophisticated and require mature thinking and calculations contest of luck. This mode promises a lot of advantages for the owner. No longer needed special of licenses to set up a gambling business via the internet. Enough to capitalize a web with exciting gambling facility, everyone can have a home of gambling on the Internet.

The criminal act of gambling increasingly complex demands of law enforcement officers to be more professional and have more ability in uncovering the crime, both in terms of investigation and proof in peradilan.Peraturan legislation will be updated when rated no weaknesses in law enforcement. It is expected to narrow the space for the perpetrators gambling in Indonesia and restore the function of the law in the eyes of society so that gambling could soon be eradicated and left unimpressed.

Based on the description above background, the formulation of the issues discussed was how the implementation of the Act on Information and Electronic Transactions (ITE) in the investigation of the Crime of Online gambling?

\section{Results And Discussion}

Online gambling is one of the criminal acts of cyberspace (cybercrime) has a negative impact so widespread and more dangerous than conventional gambling, either for other internet users unlimited access make this criminal offense into a criminal offense across the country. State of Indonesia as a state of law has regulated the crime of criminal responsibility related to online gambling. Settings banning the offense stipulated in Article 303 and Article 303 bis the Code of Penal and some of the rules outside the draft Criminal Code, namely, Act No. 7 of 1974 on Gambling Control, Article 27 paragraph (2) of the Constitution of the Republic of Indonesia Number 11 Of 2008 on Information and Electronic Transactions (Act of ITE), and Government Regulation No. 9 of 1981 on the implementation of the Gambling Control. Broadly speaking, the system of criminal responsibility in the crime of online gambling using a system of criminal liability of corporate participation and accountability systems.

So that both the individual human being or a legal entity (natural person) can be held

\footnotetext{
${ }^{6}$ Peter Mahmud Marzuki Penelitian Hukum Jakarta: Kencana Prenada Media Group 2014 p. 141.
} 
criminal liability if they committed the crime of online gambling. Although the Law of the Republic of Indonesia Number 11 Of 2008 on Information and Electronic Transactions (Act of ITE) regulates gambling control more specifically, but in practice the law - this law can not be separated from the Criminal Code as general rules. Because the basic elements like "everyone", "without right", and the element of "payload gambling" remains to be proven dengann refer to the explanation of the Criminal Code.

In a process of resolving criminal cases, must be sought for a material truth. The search for truth is certainly material to go through the verification suatuproses, a most important process in the procedural law of criminal procedure in the criminal field. The law know their stuff and proof of evidence, both of which are required in court to prove the offenses charged against the accused. Evidence or corpus delicti are objects that are involved in a crime. ${ }^{7}$ While the legal evidence to be presented before the court, as provided for in Article 184 Criminal Procedure Code are:

- Witness statement

- Description expert

- Letter

- Hint

- Description defendant.

Furthermore, the evidence relating to the crime of gambling in a deep Article 1 (2) Criminal Procedure Code: ${ }^{8}$ "Investigation is investigating a series of actions in the case and according to manner contemplated in this law to seek and submit the evidence with evidence that shed light on criminal acts that occur and to find the suspects. "

However, an investigation into the crime of gambling are still obstacles when confronted with internet gambler via verification process, as in the Criminal Code does not set any elements that contain the information technology, while in the case of gambling through internet (Internet gambling) is all done through the medium of internet. Therefore to overcome the internet gambling conducted, has issued Law of the Republic of Indonesia Number 11 of 2008 on Information and Electronic Transactions (Act of ITE), with the threat of Article 45 paragraph (1) which reads:

"Everyone who meets Pasal27 elements referred to in paragraph (1), paragraph (2), paragraph (3), or paragraph (4) shall be punished with imprisonment of six (6) years and / or a fine of Rp1.000.000.000, 00 (one billion rupiah). "9

In the Law of the Republic of Indonesia Number 11 Of 2008 on Information and Electronic Transactions (Act of ITE) have also been set up on Forbidden Acts ie including online gambling article 27 described in paragraph (2), namely:

"Any person intentionally and without right distributed and / or transmitting and / or make the inaccessibility of Electronic Information and / or Electronic Document which has gambling content."

Law of the Republic of Indonesia Number 11 Of 2008 on Information and Electronic Transactions (Act of ITE) specifically regulates the crime of gambling done using online media. Further elements of article 27 paragraph (2) of the Constitution of the Republic of Indonesia Number 11 Of 2008 on Information and Electronic Transactions (Act of ITE) is

\footnotetext{
${ }^{7}$ Ratna Nurul Afiah Barang Bukti dalam Proses Pidana Jakarta:Sinar Grafika 1989 p.14.

${ }^{8}$ The Code of Criminal Procedure

${ }^{9}$ Law of the Republic of Indonesia Number 11 Of 2008 on Information and Electronic Transactions.
} 
described as follows.

First, everyone, that the word "everyone" or "anyone" or "hijj" The elements of this article shows that the one person (naturlijk persoon), which should be held accountable for criminal acts. ${ }^{10}$ In fact, the elements of Article "everyone" is very important in terms of determining who will be the defendant in qasu. Meanwhile, the person in question in the case of such criminal acts are to be found guilty. ${ }^{11}$

Secondly, by accident, in which the formulation of a crime, intentionally placed precede the act and object elements of crime. Based deliberately relationship with other elements, then intentionally should be interpreted, that the maker wants deeds offer or participate gambling business activities. ${ }^{12}$ The element of "deliberately" included in the element of fault or an offense dolus (dolous delict).

Third, without rights, which can be interpreted that the element without the right is no authority or actions that conflict with the law and or required a permit from the authorities. In any criminal offense against the laws it contains elements, although these elements are not always stated explicitly in the formulation of crime. In Article 27 paragraph (2) uses the term "without right" to use the elements against the law.

While distributing the word comes from the word "distribution" which means "distribution (the distribution, delivery) to multiple people or to several places". ${ }^{13}$ Verb "distribute", which means to distribute or share or send an to a few (many) people or to several places. $^{14}$

While the "transmit is send or forward a message from a person (object) to another person (other objects). ${ }^{15}$ Said access means driveway, ${ }^{16}$ or overalls. ${ }^{17}$ Said access this shows that the act is an act which consists in the use of information technology berbasi computer system. Make inaccessibility, is to make electronic information with computer-based electronic systems can be received by the (instrument) receiver Electronic Information.

In formulating the material offense where elements of the illicit result was not listed separately in the act, but has been found in the element behavior. That is to formulate elements of behavior that, already by itself in it has an element of due limits. ${ }^{18}$ Element inaccessibility made in article 27, paragraph 2 of the Law of the Republic of Indonesia Number 11 Of 2008 on Information and Electronic Transactions (Act of ITE) is an act which does not separate the elements due to the forbidden.

With the issuance of Act No. 11 of 2008 on Information and Electronic Transactions, which extend pengertianalat evidence as provided for in Article 184 Criminal Procedure Code before the Law of the Republic of Indonesia Number 11 Of 2008 on Information and Electronic Transactions (Act of ITE) has accommodated the electronic evidence which can

\footnotetext{
${ }^{10}$ Eddy O.S Hiariej Prinsip-Prinsip Hukum Pidana Yogyakarta: Cahaya Atma Pustaka 2014 p. 121.

${ }^{11}$ Ibid p. 123.

${ }^{12}$ Masruchin Ruba'i dkk Buku Ajar Hukum Pidana Malang:Banyumedia Publishing 2014 p. 61.

${ }^{13}$ Kamus Besar Bahasa Indonesia Pusat Bahasa Jakarta: Penerbit PT Gramedia Pustaka Utama 2008 p. 336.

${ }^{14}$ Ibid p. 336.

${ }^{15}$ Ibid p. 1485.

${ }^{16}$ Ibid p. 30.

${ }^{17}$ Emi Zul dan Ratu Aprilia Senja Kamus Lengkap Bahasa Indonesia Jakarta: Difa Publisher 2010 p. 35.

${ }^{18}$ Adami Chazawi. Stelsel Pidana Tindak Pidana Teori-Teori Pemidanaan dan Batas-Batas Berlakunya Hukum Pidana RajaGrafindo Persada Jakarta 2010 p. 127.
} 
dipakaidalam procedural law in Indonesia. There are two important things in the Law on Information and Electronic Transactions regarding online gambling as criminal act the proof are:

- Digital evidence in Article 1 (1) and paragraph (4).

Paragraph (1) "Electronic information is one or a set of electronic data, including but not limited to text, sound, pictures, maps, plans, photographs, electronic data interchange (EDI), electronic mail, telegram, telex or telecopy or the like, letters, signs, numbers, access codes, symbols, or perforations that have been processed that has meaning or can be understood by the people. "

Paragraph (4) "Electronic Document means any electronic information created, transmitted, sent, received, or stored in the form of analog, digital, electromagnetic, optical, or the like, which can be viewed, displayed and / or heard through the Computer or Electronic Systems, including but not limited to text, sound, pictures, maps, plans, photographs or the like, letters, signs, numbers, access codes, symbols or perforation that have meaning or significance or can be understood by people who are able to understand. "

- Electronic evidence that could be used in the procedural law in Indonesia stated in Article 5 (1), (2) and (3)

Paragraph (1) "Electronic Information and / or Electronic Document and / or hasilcetaknya a valid legal evidence."

Paragraph (2) "Electronic Information and / or Electronic Document and / or printing referred to in paragraph (1) is expansion of valid evidence in accordance with the Law of Procedure which regulated companies."

Paragraph (3) "Electronic Information and / or Electronic Documents Electronic Systems declared legal when used regulated in accordance with the provisions of this Act."

Law of the Republic of Indonesia Number 11 Of 2008 on Information and Electronic Transactions (Act of ITE) has been expansion or adding other types of evidence that the new law with stated that the information and / or electronic documents and / or printing recognized as valid evidence in the trial. Goods-evidence such electronic devices as well as electronic records as form evidence of money transactions through a bank account to the owner of the gambling sites, ownership ID and gambling sites visited, SMS, BBM (blackberry messenger), email, computers, mobile phones, modems and electronic access more charged gambling has been considered as an evidence.

With the expansion of legal evidence in accordance with regulation the provisions above, the expected enforcement of gambling through internet can do more leverage. Then electronic evidence can also be used as guidelines for investigation with development widely in activity monitor on online gambling in Indonesia.

\section{Closing}

\subsection{Conclusion}

- Online gambling criminal offense or a criminal act of gambling in general, is a disease that must be eradicated society down to its roots. Where necessary earnest role of law enforcement authorities and communities to work together in combating the crime of online gambling. 
- In a criminal investigation of online gambling, there are still many cases of the crime of online gambling where the application of the rules are still using the settings the crime of gambling in general, which should in this case is already enforceable legislation more specifically (lex), Where in law more specific is Law of the Republic of Indonesia Number 11 Of 2008 on Information and Electronic Transactions (Act of ITE), The threat of punishment given to the perpetrators of such offenses more weight that imprisonment of a maximum of 6 (six) years and a maximum fine Rp.1.000.000.000, (one billion rupiah) and this will certainly be making the perpetrators of internet based online gambling is more fear to commit such offenses.

\subsection{Suggestion}

There needs to be new legislation related to online gambling in order to specifically address the parties that may be sanctioned either of actors / players directly and those involved with the crime. As well as those who provide facilities and opportunities can also be subject to criminal sanctions. Additionally, you can also repair existing arrangements in the Criminal Code and Act No. 7 of 1974 so that the legislation can provide a deterrent for criminals.

\section{Bibliography}

[1] Afiah Ratna Nurul 1989 Barang Bukti dalam Proses Pidana Jakarta: Sinar Grafika.

[2] Chazawi Adami 2010 Stelsel Pidana Tindak Pidana Teori-Teori Pemidanaan dan Batas-Batas Berlakunya Hukum Pidana Jakarta: RajaGrafindo Persada Jakarta.

[3] Falah Muhammad Fajrul dkk. 2017 Perjudian Online: Kajian Pidana atas Putusan Nomor 1033/PID.B/2014/PN.BDG e-Journal Lentera Hukum 2 Vol. 1 University of Jember.

[4] Hiariej Eddy O.S. 2014 Prinsip-Prinsip Hukum Pidana Yogyakarta: Cahaya Atma Pustaka.

[5] Kamus Besar Bahasa Indonesia Pusat Bahasa 2008 Jakarta: PT Gramedia Pustaka Utama.

[6] Marzuki Peter Mahmud 2014 Penelitian Hukum Jakarta: Kencana Prenada Media Group.

[7] Ruba'i Masruchin dkk 2014 Buku Ajar Hukum Pidana Malang: Banyumedia Publishing.

[8] Widjojo Widyopramono Hadi, 2005 Cyber crimes dan Pencegahannya Jurnal Hukum Teknologi Fakultas Hukum Universitas Indonesia Vol 2.

[9] Wahib Abdul dan Mohammad Labib 2005 Kejahatan Mayantara (Cybercrime) Kejahatan Mayantara (Cybercrime) Bandung: Refika Aditama.

[10] Zul Emi dan Ratu Aprilia Senja 2010.,Kamus Lengkap Bahasa Indonesia Jakarta: Difa Publisher.

[11] Act No. 7 of 1974 on Gambling Control.

[12] Law of the Republic of Indonesia Number 11 Of 2008 on Information and Electronic Transactions 